\title{
The Importance of Otoneurological Evaluation in Brazilian Workers Exposed to Pesticides: A Preliminary Study
}

\author{
Bianca Simone Zeigelboim ${ }^{1,2}$ Jéssica Spricigo Malisky ${ }^{1}$ Michéli Rodrigues da Rosa ${ }^{1}$ \\ Adriana Bender Moreira de Lacerda ${ }^{1,2}$ Patrícia de Souza Alcaraz ${ }^{2,3}$ Vinicius Ribas Fonseca1,2,4
}

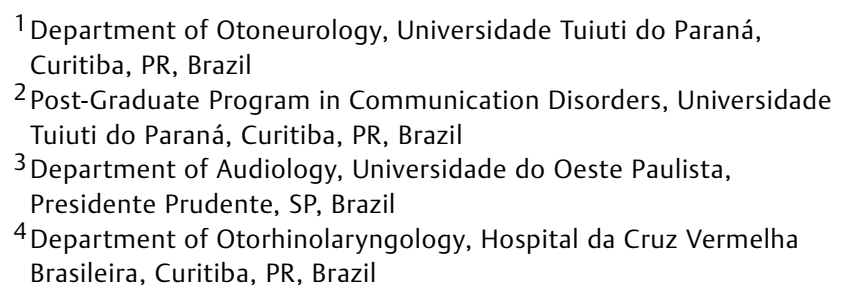

Address for correspondence Bianca Simone Zeigelboim, PhD, Rua Gutemberg, 99, 9o andar, 80420-030, Curitiba, PR, Brazil (e-mail: biancacwb@yahoo.com.br).

Int Arch Otorhinolaryngol 2019;23:e389-e395.

\begin{abstract}
Introduction Agrochemicals, also known as pesticides, are widely used in agriculture and in public health. They are organic and inorganic chemical substances with a high level of toxicity not only for the environment, but also for human health.

Objective To verify findings on labyrinthine assessment in endemic disease control agents, and to recommend the inclusion of the vestibular exam in the set of tests for pesticide-exposed populations.

Methods Descriptive, prospective, cross-sectional study with a sample comprising 15 endemic disease control agents, males, mean age of 51.6 years old (standard deviation $[S D]=5.9)$. All of the participants were submitted to anamnesis, otorhinolaryngological screening, and vestibular assessment.

Results Regarding the most reported complaints, dizziness (73.4\%), headache (60\%), and tingling in the extremities (53.4\%) were observed. The findings of the vestibular

\section{Keywords}

- occupational risks

- dizziness

- pesticides

- pesticide exposure

- organophosphate insecticides

- toxicity exams were normal in $53.3 \%$, while $46.7 \%$ showed peripheral vestibular disorder, of which $26.7 \%$ were of deficitary type, and $20 \%$ of the irritative type.

Conclusions: Alteration in the vestibular system was verified in $50 \%$ of the workers, with a greater prevalence in the caloric testing. Several disorders related to pesticides intoxication are scientifically known. Actions promoting knowledge and qualification of this population for the proper handling of chemicals are suggested, in addition to the elaboration and inclusion of protocols of vestibular assessment in hearing health programs for the prevention, diagnosis and treatment of vestibular disorders.
\end{abstract}

\section{Introduction}

In the past 10 years, the Brazilian market of pesticides has grown 190\%, which has made Brazil the largest consumer of these substances since $2008 .{ }^{1}$ According to data from the

received

February 3, 2018

accepted

February 13, 2019

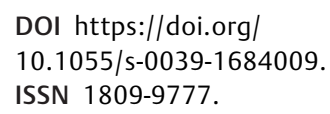

Brazilian Institute of Geography and Statistics (IBGE, in the Portuguese acronym), ${ }^{2}$ during the past years, there has been an annual increase of $6.9 \mathrm{Kg} / \mathrm{ha}$ in agrochemicals sales in Brazil, with incremented their use in the rural area. Since 2008, Brazil has been the global leader in pesticide consumption. ${ }^{3}$ The

Copyright (@) 2019 by Thieme Revinter Publicações Ltda, Rio de Janeiro, Brazil

\section{License terms}

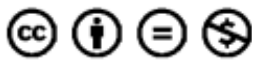


most recent data by the Information System on Diseases of Compulsory Declaration of the Brazilian Ministry of Health (SINAN/MS, in the Portuguese acronym) show that acute intoxications by agrochemicals rank second among the reported exogenous intoxications. According to the World Health Organization and the Pan-American Health Organization (WHO/PAHO), ${ }^{4}$ the number of cases increased $67.3 \%$ between 2007-2011.

Agrochemicals, known as pesticides, widely used in agriculture and in public health, are organic and inorganic chemical substances with a high level of toxicity, not only for the environment, but also for human health. ${ }^{5}$

Excessive exposure to agrochemicals, associated with the absence of individual protection, has caused severe intoxications, mainly in farmers and in endemic disease control agents. $^{5}$ To the $\mathrm{WHO} / \mathrm{PAHO}$, in the future, 3 million workers are estimated to present with some sort of agrochemical intoxication, and 220 workers may die a year; $70 \%$ of those deaths will occur in the so-called Third World countries. ${ }^{6}$

For decades, aiming at eliminating the agents of plagues and diseases, the health area has been relying on agrochemicals to do away with the vectors of endemic diseases. Recently, supervised by the National Health Foundation (FNS, in the Portuguese acronym), campaigns against endemic vectors, such as Zika, Chikungunya and Dengue, have been using organophosphate and pyrethroid insecticides, being Malathion the most commonly used in these campaigns. Their level of toxicity is publicly known, which features a hazardous condition for the exposure of workers in the programs and campaigns of municipal health secretaries. ${ }^{7}$

Agrochemical intoxication may occur in three ways: inhalation, ingestion and skin absorption. Organophosphate agrochemicals and pyrethroids are known for their anticholinesterase effect, that is, they inhibit the acetylcholine enzyme, which is, according to the literature, an efferentcontrol neurotransmitter for the vestibular system. ${ }^{8}$

To Morata et al, ${ }^{9}$ agrochemicals may cause severe disorders in the vestibular system, associated with the impairment of the brainstem and of the cerebellum. In the labyrinthine testing, the presence of central positional nystagmus, vestibulo-ocular hyporeflexia or hyperreflexia, and absence of the inhibition effect of visual fixation in the caloric testing can be observed. According to Andrade, ${ }^{3}$ agrochemical exposure may cause injuries to the hair cells of the crista ampullaris of the semicircular canals, and to the macula hair cells of the saccule and utricle, which are responsible for balance. The degree of the lesion caused by those substances will depend on individual predisposition, administered dose, duration, route of administration, age, and family tendency. ${ }^{10}$

Studies on pesticide effects (organophosphates or pyrethroids) over the vestibular system are still very insipient. Research, which investigates vestibulotoxicity and neurotoxicity, enables to refine the knowledge on the direct effect of chemicals on the vestibular system.

Therefore, the present study aims to verify findings on labyrinthine assessment in endemic disease control agents, and recommends the inclusion of the vestibular exam in the set of tests for pesticide-exposed populations.

\section{Methods}

\section{Participants and Study Design}

The present study was approved by the Ethics Board-Brazil Platform-opinion number 1.242.014/2015, and was authorized by the participants after having signed the Free Informed Consent Form.

The present study is a descriptive, prospective, cross-sectional study with the participation of 15 endemic disease control agents, all males, aged between 49 and 67 years old, mean age of 56.1 years old (standard deviation $[S D]=5.9$ ), referred by the Union of Federal Civil Servants on Health, Labor, Social Security and Social Action for evaluation at the Otoneurology Department of a Higher Education Institution. The research included workers $>18$ years old, exposed to organophosphate and pyrethroid agrochemicals for $>20$ years, with a mean of 32.4 years (standard deviation $=4.3$ ), and excluded workers (endemic disease control agents) $<18$ years old, suffering from major neurological, psychological, visual and/ or musculoskeletal disorders, in addition to otological disorders, such as presence of cerumen and otorrhea, which could prevent them from undergoing the exam.

\section{Procedures}

Anamnesis - the questionnaire was applied, focusing on otoneurological signs and symptoms (-Fig. 1).

Otorhinolaryngological Assessment - this was performed to rule out any alterations that could affect the testing.

\section{Vestibular Assessment}

The workers underwent the following tests that make up the vestibular examination. Initially, we checked vertigo and spontaneous and semispontaneous positional nystagmus.

Thus, we have used digital vector electronystagmography (VENG), which has its own software: VecWin2 (Neurograff Eletromedicina Ltda., São Paulo, São Paulo, Brazil), a Ferrante COD 14200 rotating chair with a rotation of between 0.01 and $0.5 \mathrm{~Hz}$, (Ferrante, São Paulo, São Paulo, Brazil), an EV VEC visual stimulator (Neurograff Eletromedicina Ltda., São Paulo, São Paulo, Brazil), and an air NGR 05 caloric stimulator (Neurograff Eletromedicina Ltda., São Paulo, São Paulo, Brazil). The flow rate used was of 5 and $13 \mathrm{~L} / \mathrm{min}$.

Next, we conducted the eye and labyrinth VENG tests, according to the criteria proposed by Mangabeira-Albernaz et al. ${ }^{11}$

Eye movement calibration - We verified spontaneous and semi-spontaneous nystagmus using pendular tracking, checking for pre- and postrotatory plus pre- and postcaloric optokinetic nystagmus. We recorded the caloric stimulation time in each ear using air at $42^{\circ} \mathrm{C}$ and $18^{\circ} \mathrm{C}$ during 80 seconds for each temperature, and responses with closed eyes and then with open eyes to observe the inhibitory effect of eye fixation (IEEF). The criteria used in the air caloric test were: absolute value between 2 and 24 degrees/second, with $<2$ degrees/second corresponding to hyporeflexia; and with $>24$ degrees/second corresponding to hyperreflexia; relative values of labyrinth preponderance $(\mathrm{LP})<41 \%$ and nystagmus directional preponderance $(\mathrm{NDP})<36 \%{ }^{12}$ 


\section{ANAMNESIS}

\section{IDENTIFICATION}

DATE: / /

Name:

Age:

Country of Birth:

Date of Birth:

Race:

Occupation:

\section{PROFESSIONAL ACTIVITY}

Previous jobs:

Total time working: in noisy place exposed to chemical agents:

Is currently ( ) or has been ( ) exposed to chemical agents:

heavy metals (lead, mercury): asphyxiants $\left(\mathrm{CO}_{2}\right)$ :

\section{HISTORY OF MORBIDITY}

Smokes ( ) or has been a smoker ( ) how many packs per day? __ How many cigarettes per day?

Regularly consumes alcohol? ( ) no ( ) yes - how much per day:

Consumes caffeine? ( ) no ( ) yes - how much per day:

Dietary errors:

Takes medication? ( ) no yes ( ) Which ones:

Had surgery? ( ) no yes ( ) What:

Identify subject's health problems:

\begin{tabular}{|c|c|c|c|}
\hline SIGNS AND SYMPTOMS & YES & NO & $\begin{array}{c}\text { MEDICATION } \\
\text { TAKEN }\end{array}$ \\
\hline \multicolumn{4}{|l|}{ Change in blood flow } \\
\hline \multicolumn{4}{|l|}{ Hypertension } \\
\hline \multicolumn{4}{|l|}{ Sensitivity change } \\
\hline \multicolumn{4}{|l|}{ Incoordination of movement } \\
\hline \multicolumn{4}{|l|}{ Sensation of movement of objects } \\
\hline \multicolumn{4}{|l|}{ Diabetes } \\
\hline \multicolumn{4}{|l|}{ Thyroid dysfunction } \\
\hline \multicolumn{4}{|l|}{ Cranioencephalic Trauma } \\
\hline \multicolumn{4}{|l|}{ Heart disease } \\
\hline \multicolumn{4}{|l|}{ Kidney damage } \\
\hline \multicolumn{4}{|l|}{ Rheumatologic disorders } \\
\hline \multicolumn{4}{|l|}{ Degenerative Diseases } \\
\hline \multicolumn{4}{|l|}{ TMJ disorder } \\
\hline \multicolumn{4}{|l|}{ Dysarthria } \\
\hline \multicolumn{4}{|l|}{ Alteration in smell/ taste } \\
\hline \multicolumn{4}{|l|}{ Pain/difficulty in moving neck } \\
\hline \multicolumn{4}{|l|}{ Tingling in extremities } \\
\hline \multicolumn{4}{|l|}{ Dysphonia } \\
\hline Dysphagia & & & \\
\hline
\end{tabular}

Fig. 1. Anamnesis by Otoneurology Department. Abbreviation: TMJ, Temporomandibular Joint disorder. 
e392 The Importance of Otoneurological Evaluation in Brazilian Workers Zeigelboim et al.

\begin{tabular}{l}
\hline Double/blurred vision \\
\hline Fatigue \\
\hline Anxiety/ fear/depression \\
\hline Headache/migraine \\
\hline
\end{tabular}

\section{HEARING LOSS:}

Onset:_ Locale: ( ) right ear ( ) left ear ( ) both

Intensity:_ Occurrence:__ Pain in ear: ( ) yes ( ) no

Purging in ear: ( ) yes ( ) no

Appears or worsens:

Triggering factors:

Aggravating factors:

Factors for improvement:

Concomitant symptoms:

\section{DIZZINESS}

Onset:

Definition:

Intensity:

Occurrence:

Duration ( ) seconds ( ) minutes ( ) hours ( ) days

Appears or worsens:

( ) nausea ( ) vomiting ( ) sweating ( ) gait imbalance ( ) falling

Triggering factors:

Aggravating factors:

Factors for improvement:

Concomitant symptoms:

\section{TINNITUS}

Onset:

head ( ) type :

Definition:

Occurrence:

Appears or worsens:

Triggering factors:

Aggravating factors:

Factors for improvement:

Concomitant symptoms:

\section{NONOCCUPATIONAL EXPOSURE}

Is exposed for more than four hours: ( ) motorcycle ( ) loud music ( ) tools

( ) farming equipment ( ) firearm shooting

What does the subject do in free time?

Does the subject have hobbies?

Fig. 1. (Continued). 


\section{Statistical Analysis}

For the analysis of the results, methods of descriptive statistics were used (frequency tables), as well as the Fisher exact test, correlating the result of the vestibular testing to the most reported otoneurological symptoms. The rejection level established to the null hypothesis was of 0.05 or $5 \%$ with the Statistica 13.1 (StatSoft, Inc., Tulsa, OK, USA) software.

\section{Results}

The most reported complaints in the anamnesis were dizziness (73.4\%), headache, and tingling in extremities (53.4\%), as shown in - Table 1 .

In the vestibular function assessment, the check for the spontaneous nystagmus with closed eyes $(6.7 \%)$ and with caloric stimulation (40\%) was altered in the endemic disease control agents.

Regarding the result of the vestibular testing, normoreflexia was observed in $53.3 \%$ of the subjects, and peripheral vestibular disorder in $46.7 \%$, of which $26.7 \%$ were of deficitary type, and 20\% of irritative type, as shown in - Table 2.

The correlation between agrochemicals and the three most evidenced otoneurological symptoms can be observed in - Table 3.

Table 1 Symptoms in 15 workers

\begin{tabular}{|l|l|l|}
\hline Symptoms & $\begin{array}{l}\text { Workers } \\
(\boldsymbol{n})\end{array}$ & $\begin{array}{l}\text { Frequency } \\
(\%)\end{array}$ \\
\hline Dizziness & 11 & 73.4 \\
\hline Headache & 9 & 60.0 \\
\hline Tingling in extremities & 8 & 53.4 \\
\hline Anxiety & 4 & 26.7 \\
\hline Tinnitus & 3 & 20.0 \\
\hline Pain, difficulty in neck movement & 3 & 20.0 \\
\hline Insomnia & 3 & 20.0 \\
\hline Fatigue & 2 & 13.4 \\
\hline Hearing Loss & 2 & 13.4 \\
\hline High pressure & 2 & 13.4 \\
\hline Depression & 2 & 13.4 \\
\hline Pain, irradiated to shoulder, arm & 1 & 6.7 \\
\hline Taste alteration & 1 & 6.7 \\
\hline Double vision & 1 & 6.7 \\
\hline
\end{tabular}

Table 2 Frequency of the vestibular testing results in 15 workers

\begin{tabular}{|l|l|l|}
\hline \multirow{2}{*}{ Vestibular Testing } & \multicolumn{2}{|l|}{ Workers } \\
\cline { 2 - 3 } & $\boldsymbol{n}$ & $\%$ \\
\hline Peripheral vestibular dysfunction & 7 & 46.7 \\
\hline Normal vestibular testing & 8 & 53.3 \\
\hline Total & 15 & 100.0 \\
\hline
\end{tabular}

Abbreviations: $n$, number of workers; \%, frequency.
Table 3 Correlation between the vestibular testing result and the most evidenced otoneurological symptoms in 15 workers

\begin{tabular}{|l|l|l|l|l|l|l|}
\hline \multirow{2}{*}{$\begin{array}{l}\text { Vestibular } \\
\text { Testing }\end{array}$} & \multicolumn{2}{|l|}{ Dizziness } & \multicolumn{2}{l|}{$\begin{array}{l}\text { Tingling in } \\
\text { extremities }\end{array}$} & \multicolumn{2}{l|}{ Headache } \\
\cline { 2 - 7 } & $n$ & $\%$ & $n$ & $\%$ & $n$ & $\%$ \\
\hline $\begin{array}{l}\text { Normal } \\
\text { vestibular } \\
\text { testing }\end{array}$ & 7 & 46.7 & 4 & 26.7 & 4 & 26.7 \\
\hline $\begin{array}{l}\text { Abnormal } \\
\text { vestibular } \\
\text { testing }\end{array}$ & 4 & 26.7 & 4 & 26.7 & 5 & 33.3 \\
\hline Total & 11 & 73.4 & 8 & 53.4 & 9 & 60.0 \\
\hline
\end{tabular}

Abbreviations: $n$, number of workers; \%, frequency.

By applying the Fisher exact test, no significant difference was verified in the correlation between the result of the vestibular testing and the following symptoms: dizziness, headache, and tingling in extremities $(p=0.7170)$.

\section{Discussion}

In the analysis of the anamnesis, the occurrence of multiple neurological symptoms was verified, among them: dizziness (73.4\%), headache (60\%), and tingling in extremities (53.4\%). According to the literature, symptoms such as dizziness and headache are commonly reported in agrochemical intoxication. ${ }^{13-15}$ In addition to those symptoms, Lakhani et $\mathrm{al}^{16}$ reported sensorineural hearing loss and tinnitus as part of the prevalent symptomatology in the exposure to organophosphates. To Hoshino et al, ${ }^{15}$ dizziness is a major symptom, considered one the most outstanding clinical manifestations to agrochemical exposure.

Delgado et al ${ }^{17}$ applied a questionnaire to 55 farmers on the use of agrochemicals, and observed that $92 \%$ of those workers did not use any personal protection equipment to handle the products; $62 \%$ reported discomfort during their handling, and the referred symptoms were: headache, nausea, vomiting, vertigo, skin rash, and blurred vision.

According to Tuma et al, ${ }^{18}$ the central nervous system (CNS) is responsible for processing and organizing sensory information, resulting in proper ocular and spinal reflexes to keep the postural balance in the environment, as well as the static and dynamic spatial orientation, which justifies the complaint of dizziness reported by workers exposed to agrochemicals.

Regarding the vestibular assessment, alteration in the vestibular system in $46 \%$ of the workers, higher prevalence in the caloric testing, with predominance of the peripheral vestibular deficitary syndrome, were observed in the present study. These finding are in line with studies by Hoshino et al, ${ }^{15}$ who assessed 18 rural workers exposed to organophosphates, and observed peripheral vestibular disorders in $89 \%$ of the cases. The reported dysfunctions were observed when they checked for nystagmus, and/or positional vertigo, and hyperreflexia to the caloric testing. In another study, ${ }^{19}$ the authors checked 50 rural workers exposed to organophosphate agrochemicals for hearing and vestibular symptoms, and reported that $76 \%$ complained about dizziness episodes, $58 \%$ reported 
daily dizziness, 54\% complained about tinnitus, and $46 \%$ reported ear fullness. The authors observed that agrochemicals may cause hearing and vestibular systems disorders. A study by de Araújo et $\mathrm{al}^{20}$ assessed the vestibular system of workers exposed to organophosphates, and evidenced alterations in the caloric testing, unveiling irritative peripheral vestibular dysfunction. The authors showed that these chemicals have neuro-ototoxic potential; however, the safe dosage and exposure time, so that those chemicals are not deleterious to health, cannot be stated. To Werner, ${ }^{21}$ organophosphates have, as their main action mechanism, the inhibition of the acetylcholinesterase enzyme, responsible for the degradation of the acetylcholine neurotransmitter, which performs the synapses in the peripheral and CNS.

Körbes et $\mathrm{al}^{22}$ performed a study with guinea pigs submitted to agrochemical exposure and considered organophosphates an acute lesion agent of the outer hair cells, as there is a correlation between the applied dosage and the amount of alterations observed by means of electronic microscopy. The morphological injuries in the cochlea prevailed in the stereocilia of the outer hair cells, progressing to the basal spiral. The authors reported morphological cochlea alterations in the saculle and utricle of guinea pigs exposed to a daily dosage of organophosphates, evidencing the degrading effect of agrochemicals to the vestibulocochlear system.

Occupational ototoxicity caused by chemicals, including pesticides, has called scarce attention on the part of health professionals. Therefore, its impact on auditory and vestibular systems of exposed workers is a matter of concern. Injuries are known to vary according to innumerable risk factors: type of chemicals, interactions, dosages, method and time of exposure, presence of physical conditions, and individual susceptibility.

Thus, it should be pointed out that the assessment of the vestibular system in workers exposed to agrochemicals should be performed periodically by monitoring any injuries, in addition to the performance of specific clinical anamnesis.

The evaluation of complaints and symptoms associated with hearing disorders must include information on balance as well as questions related to their impact on general health and social life. Balance disorders can be a risk factor for occupational accidents. Due to lack of knowledge and of access to the exam which evaluates the vestibular function in the Brazilian Unified Health System (SUS, in the Portuguese acronym), the authors of the present study suggest the inclusion of the protocol for balance assessment to be applied to workers exposed to pesticides, which can also be extended to other chemicals (-Fig. 1). In addition, the labyrinthine testing can be suggested as part of the assessment routine.

\section{Conclusion}

The most reported otoneurological symptoms were: dizziness (73.4\%), headache (60\%), and tingling in extremities (53.4\%). Moreover, the most reported clinical symptoms were: anxiety (26.7\%), tinnitus (20\%), and neck cranking (20\%).

Disorders in the vestibular system were verified in $50 \%$ of the workers, being more prevalent in the caloric testing.
Actions promoting knowledge and qualification of this population for the proper handling of chemicals are suggested, as well as the elaboration and inclusion of protocols to vestibular assessment in programs of hearing health to prevent, diagnose, and treat vestibular dysfunctions.

\section{Institution \\ Universidade Tuiuti do Paraná (UTP), Curitiba, PR, Brazil}

Conflicts of Interest

The authors have no conflicts of interest to declare.

\section{References}

1 Carneiro F, Rigotto RLM, Augusto LGS, Friedreich K, Burigo PC. Dossiê ABRASCO: Um alerta sobre os impactos dos agrotóxicos na saúde. Rio de Janeiro: ABRASCO; 2012

2 IBGE: Uso de agrotóxico mais que dobrou de 2000 a 2012, aponta IBGE [internet]. Brasil: Instituto Brasileiro de Geografia e Estatística; cited 2015 jun 19 Available at: http://www.ibge.gov.br/. Accessed March 04, 2016

3 Andrade MIKP. Efeitos da exposição ao agrotóxico no sistema auditivo eferente através das emissões otoacústicas transientes com supressão [tese]. Rio de Janeiro: Universidade Federal do Rio de Janeiro, Departamento de Saúde Coletiva; 2012:132

4 OMS/OPAS - Organização Mundial da Saúde/ Organização PanAmericana da Saúde. Ministério da Saúde. Saúde nas Américas: panorama regional e perfis de países, Brasília, 2012

5 Silva JM, Novato-Silva E, Faria HP, Pinheiro TMM. Agrotóxico e trabalho: uma combinação perigosa para a saúde do trabalhador rural. Cien Saude Colet 2005;10(04):891-903

6 OMS/OPAS - Organização Mundial da Saúde/ Organização PanAmericana da Saúde. Ministério da Saúde. Manual de vigilância da saúde de populações expostas à agrotóxicos. Brasília, 1990

7 Teixeira CF, Augusto LGS, Morata TC. Saúde auditiva de trabalhadores expostos a ruído e inseticidas. Rev Saude Publica 2003;37 (04):417-423

8 Ishiyama A, Lopez I, Wackym PA. Distribution of efferent cholinergic terminals and alpha-bungarotoxin binding to putative nicotinic acetylcholine receptors in the human vestibular endorgans. Laryngoscope 1995;105(11):1167-1172

9 Morata TC, Lacerda ABM. Saúde auditiva. In: Zeigelboim BS, Zurkiewicz AL. Multidisciplinaridade na otoneurologia. São Paulo: Roca; 2013:386-399

10 Cogo LA, Santos Filha VAV, Murashima AdeA, Hyppolito MA, Silveira AF. Morphological analysis of the vestibular system of guinea pigs poisoned by organophosphate. Rev Bras Otorrinolaringol (Engl Ed) 2016;82(01):11-16

11 Mangabeira-Albernaz PL, Ganança MM, Pontes PAL. Modelo operacional do aparelho vestibular. In: Mangabeira-Albernaz PL, Ganança MM. Vertigem. 2. ed. São Paulo: Moderna; 1976:29-36

12 Costa KCF, Silva SMR, Ganança CF. Estudo das provas oculomotoras e vestibulares por meio da vectonistagmografia. Distúrb Comun 2005;17:315-322

13 Ames RG, Steenland K, Jenkins B, Chrislip D, Russo J. Chronic neurologic sequelae to cholinesterase inhibition among agricultural pesticide applicators. Arch Environ Health 1995;50(06):440-444

14 Pires DX, Caldas ED, Recena MCP. Intoxicações provocadas por agrotóxicos de uso agrícola na microrregião de Dourados, Mato Grosso do Sul, Brasil, no período de 1992 a 2002. Cad Saude Publica 2005;21(03):804-814

15 Hoshino AC, Pacheco-Ferreira H, Taguchi CK, Tomita S, Miranda MF. Estudo da ototoxicidade em trabalhadores expostos a organofosforados. Rev Bras Otorrinolaringol 2008;74(06):912-918

16 Lakhani R, Bleach N. Carbon monoxide poisoning: an unusual cause of dizziness. J Laryngol Otol 2010;124(10):1103-1105 
17 Delgado IF, Paumgartten FJ. Intoxicações e uso de pesticidas por agricultores do Município de Paty do Alferes, Rio de Janeiro, Brasil. Cad Saude Publica 2004;20(01):180-186

18 Tuma VC, Ganança CF, Ganança MM, Caovilla HH. Avaliação oculomotora em pacientes com disfunção vestibular periférica. Rev Bras Otorrinolaringol 2006;72(03):407-413

19 Hoshino ACH, Pacheco-Ferreira H, Taguchi CK, Tomita S, Miranda MF. A auto-percepção da saúde auditiva e vestibular de trabalhadores expostos a organofosforados. Rev CEFAC 2009;11(04): 681-687
20 de Araújo AJ, de Lima JS, Moreira JC, et al. Exposição múltipla a agrotóxicos e efeitos à saúde: estudo transversal em amostra de 102 trabalhadores rurais, Nova Friburgo, RJ. Cien Saude Colet 2007;12(01):115-130

21 Werner AF. Afecciones auditivas de origen ocupacional: de la prevención a la rehabilitación. Buenos Aires: Dosyuna; 2006

22 Körbes D, Silveira AF, Hyppolito MA, Munaro G. Ototoxicidade por organofosforados: descrição dos aspectos ultraestruturais do sistema vestibulococlear de cobaias. Rev Bras Otorrinolaringol (Engl Ed) 2010;76(02):238-244 